\title{
Indigenous silk moth farming as a means to support Ranomafana National Park
}

Tsiresy Razafimanantosoa', Olga R. Ravoahangimalala', Catherine L. Craig"

\author{
Correspondence: \\ Catherine L. Craig \\ 221 Lincoln Road \\ Lincoln, MA 01773 \\ Telephone: +317812599184 \\ E-mail: ccraig@cpali.org
}

uct may be wild silk. Wild silk can be sustainably harvested in remote areas and easily transported to commercial centers. To determine if wild silk is a potential means of income generation for people living in areas of Madagascar where silk has not been traditionally produced, we gathered three types of information: 1. The diversity of silk producing larvae in the Eastern Forest Corridor and specifically in Ranomafana

2. The physical properties of larval silk and their estimated commercial value

3. How to apply our data in order to select sites where wild silk production could have a maximum economic and conservation effect

We emphasize that the work reported here is preliminary and that we are working to expand our database for silkworm larvae and potential projects sites. All of these data will be posted on the website for Conservation through Poverty Alleviation (www.cpali.org) as we progress. Elsewhere we report the life-history biology of the species found to date and analyze the economic resources that will need to be generated by local communities to engage in silk production for commercial markets (Craig and Weber, in prep.).

\section{THE DIVERSITY OF SILK PRODUCING LARVAE IN RANOMAFANA}

COLLECTION APPROACH Initially, we set up black lights and white lights in multiple sites to census adult silk moths at night. We found that many of the moth species in which we were interested were not attracted to the lights. Furthermore, this approach could not give us information on the types of plants on which the females laid eggs and on which larvae fed. Therefore, we began to collect larvae with the assistance of the Ranomafana community.

Turning to the community for assistance was effective for several reasons. First, the collecting program proved a valuable tool for educating the local population about our program and greatly increased our visibility in Ranomafana. Second, the local people were better at finding the silkworms then we were, and covered a broader area than our team could search. 
TABLE 1. Summary of larvae collecting program. Due to disparity in sample size, statistical analyses are not appropriate. Nevertheless, many more local residents collected larvae when an equal value of rice was offered instead of money

\begin{tabular}{|c|c|c|c|c|}
\hline \multicolumn{2}{|c|}{ MONEY (5CM ABOUT 5000 FMG) } & $\begin{array}{c}\text { LARVAE } \\
\text { (2CM }=\text { CUP OF RICE) }\end{array}$ & \multicolumn{2}{|c|}{ RICE } \\
\hline Number of payments & 96 & & Number of payments & 31 \\
\hline Number of days & 39 & & Number of days & 4 \\
\hline Number of larvae & 441 & & Number of larvae & 106 \\
\hline Average payment of larvae & $\begin{array}{l}3,315 \text { FMG } \\
\text { (0.33 US\$) }\end{array}$ & & Average payment of larvae & 3 cups of rice \\
\hline $\begin{array}{l}\text { Uses of US\$ } \\
\text { Food } \\
\text { Supplies } \\
\text { Recreation }\end{array}$ & \begin{tabular}{l|}
$68 \%$ \\
$16 \%$ \\
$16 \%$
\end{tabular} & & $\begin{array}{l}\text { Uses of US\$ } \\
\text { Food }\end{array}$ & $100 \%$ \\
\hline
\end{tabular}

Third, we only accepted the target larvae of the silkworms when they were delivered together with a sample of their plant and with locality data. This allowed us to track where the villagers searched, what the larvae were eating, and for whom in the community wild silk production might be an economic benefit. The community soon learned the types of larvae we were interested in, and brought us only those. Fourth, our collecting program allowed us to conduct informal surveys to determine 1) what methods were most effective when we wanted to communicate information about our program, 2) if villagers knew what silk was, and 3) the impact of the reward on family support.

We learned that most villagers did not know what silkworms were and only a few knew that silk could be used to produce textiles. The notices posted in Malagasy at the National Park Headquarters in Ranomafana and at the Mayor's office to advertise the program had little effect to recruit participants. Instead, most individuals found out about the program by word of mouth and starting with the villages where CPALI team members lived.

Members of the community collected larvae outside the park. In exchange for larvae we offered money or an equalvalue volume of rice (Table 1). We found that many more people participated in the program when rice was exchanged for larvae. This may be simply because as the program became known to more people, or it may be that rice was more highly valued than money. In addition, rice rewards ensured that payments were used to support local families and not recreational purposes. Finally, because members of the community were only allowed to collect larvae outside of Ranomafana National Park, we learned that wild silk production could be one way to add value to the border forests that protect the park.

LARVAL DIVERSITY The diversity of silk moths found at the edge of the Ranomafana National Park was high. We found over 28 morphologically distinguishable, larval species from the family Lasiocampidae and in particular, the subfamily Gonometinae (see Figure 1 for examples). The Gonometinae species are currently used for wild silk production in Madagascar, and in most cases the silk is spun by Borocera madagascariensis or B. cajani (Lajonquiere 1972, Peigler 2004). Although we were unable to link all of the larvae with positive identifications of the adults we were able to divide the larvae into three groups, the "madagascariensis complex", the "cajani complex" and the "social complex". Table 2 is a preliminary list of species based on comparisons between photographs of the wings of adults that emerged from our cocoons, and photographs of adult specimens in the Muséum National d'Histoire Naturelle, Paris. These data need to be verified through molecular and morphological analyses and the adults need to be linked with the diverse larvae illustrated in Figure 1.

TABLE 2. Preliminary list of silk moths found in border forests at Ranomafana All identifications need molecular and morphological confirmation.

\begin{tabular}{|l|l|}
\hline GONOMETINAE & NOTODONTIDAE \\
\hline Borocera attenuata & Anaphe aurea \\
\hline B. madagscariensis & Hypsoides befotakana \\
\hline B. cajani & \\
\hline B. cajani castenea & SATURNIIDAE \\
\hline B. cajani f. gigas & Antherina suraka \\
\hline B. nigracornis & Argema mittrei \\
\hline B. mimus & Maltagorea fusicolor \\
\hline Eutropa punctillata & M. auricolor \\
\hline Phoenecladocera merina & Bunaea aslauga \\
\hline Ochanella hova & \\
\hline Acosmetoptera raharizoninai & \\
\hline Malacostala spp & \\
\hline Napta serratilinea & \\
\hline Apatelopteryx spp & \\
\hline Phoenicladocera graveaudi & \\
\hline
\end{tabular}



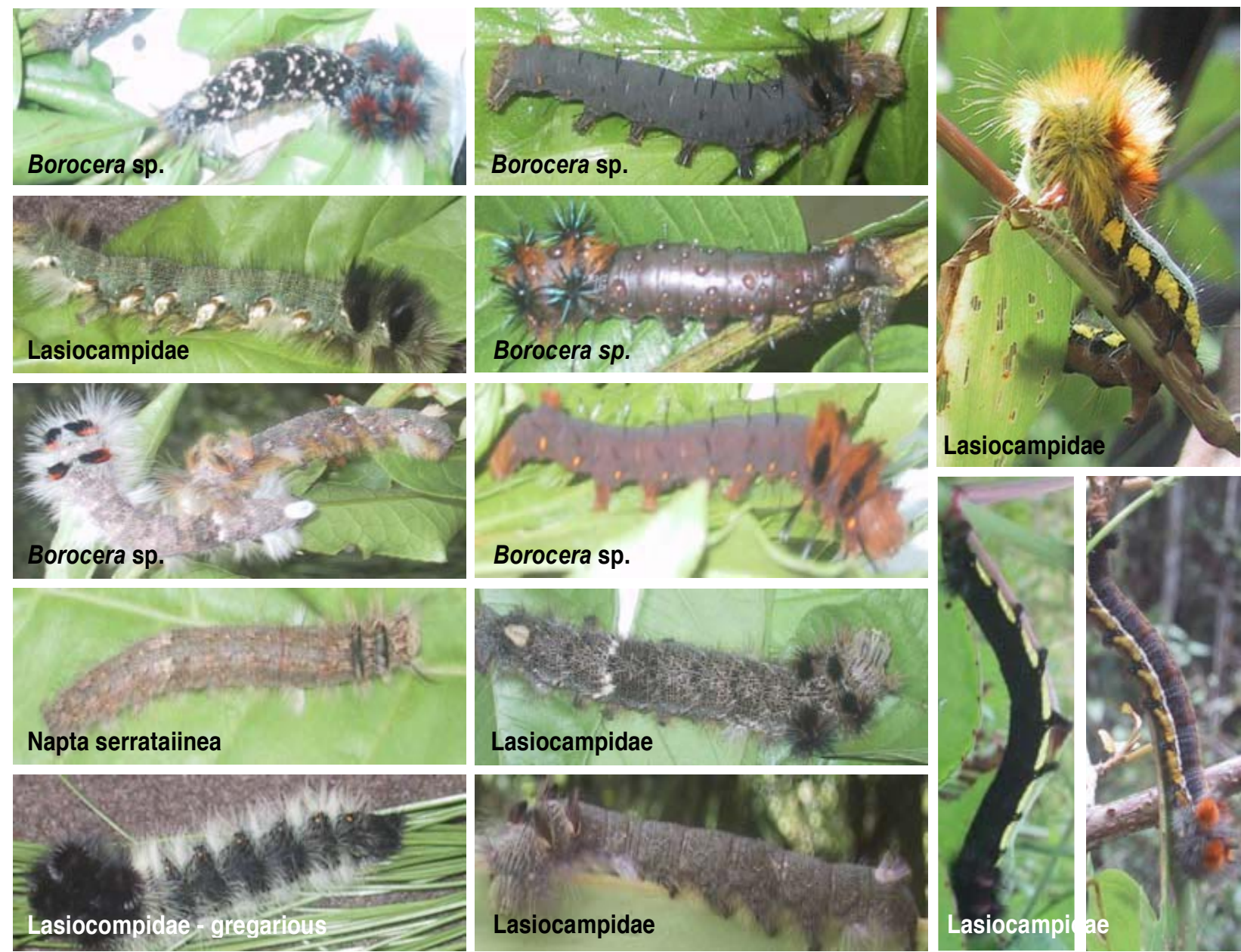

FIGURE 1. Larval diversity. We found a bewildering array of larval phenotypes, some of which are illustrated above, and have grouped them into three classes based on the distribution of spines and the emergent adults. We are currently working to develop a database of all our larvae, that will include development stages, egg photographs and natural history and that will be posted on our website. We hope to use a format similar to the ACG project (http://janzen.sas. upenn.edu/).

In addition to the diverse Gonometinae species we found in Ranomafana, we also found two species of silk moths from the family Saturniidae (Griveaud 1961), and one species of social moth from the family Thaumetopoeidae (Anaphe aurea, Thaumetopoeidae, Notodontoidea) that may be valuable for silk production (Kiriakoff 1969). None of these have been used for silk textiles in Madagascar although silks produced by Saturniidae species are used throughout Asia and silk produced by the colonial silkworms, Anaphe spp., is used for textiles in Africa (Peigler 1993, Gowdey 1953).

\section{THE PHYSICAL PROPERTIES AND COMMERCIAL VALUE OF COCOONS AND SILK PRODUCED BY NATIVE MOTHS}

Three, easily measured properties of silk and cocoons affect their commercial value: cocoon weight, the number of layers of the cocoon and fiber porosity. We observed that cocoons spun by the silk moths we reared were made up of 1-4 layers of silk. In the case of the Gonometinae, the outer layer is a paper-like husk and there are one or more soft, inner layers. In contrast, the cocoons produced by Saturniidae were always two layers and each layer was similar in weight and spun from the same silk.

Figure 3 is a plot of cocoon weight versus the number of layers. Notably, cocoon weights are highly variable even if the number of layers spun is not. The high variability in the data could be the result of two factors. Cocoon weight and layer number may reflect the type of plant on which the larvae fed. Alternatively, the variation observed might reflect different species of silkworm that we have not yet identified. For example, we know that the Malagasy silk moth Borocera cajani is made up of multiple eco-races (if not species, (Lajonquiere 1972)) and feeds on multiple plant foods (unpublished data).

In Madagascar, cocoons are sold by weight. Cocoons produced by Borocera madagascariensis in the Malagasy highlands are 2-4 times as heavy as cocoons produced by Borocera species in Ranomafana (Figure 2). Therefore, these data may indicate that the cocoons produced by Borocera spp. in the Ranomafana area are too lightweight to be of great commercial value unless 1) many individuals can be raised/found or 2) unless cocoons produced by multiple species are combined. Our preliminary data also suggest that cocoons produced by silk worms reared on guava (introduced plant species, Psidium guajava, Myrtaceae) are heavier than cocoons produced by Borocera spp. reared on other plants. Therefore, it may be that if Borocera larvae are reared on guava, cocoons produced in the Ranomafana region will be more commercially competitive. The cocoons produced by the saturniid moth Argema mittrei are approximately equal in weight to cocoons produced by $B$. mada- 

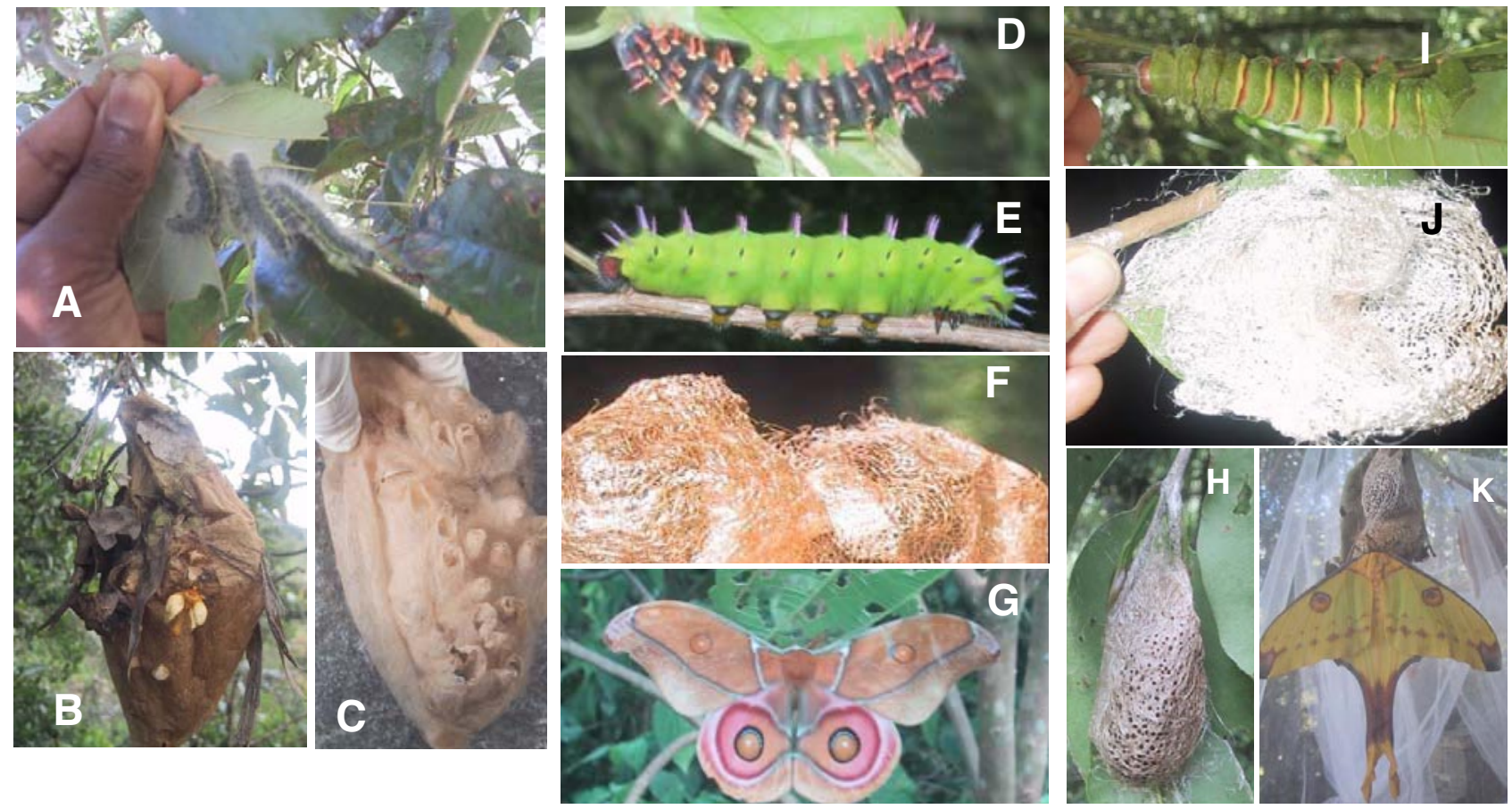

FIGURE 2. Potential producers of new types of silk could result in new income for Madagascar. A, B, C: Colonial silk moth Anaphe aurea (used for silk production in Kenya), A. larvae, B. female emerging from group cocoon, C. silk cells inside of cocoon; D, E, F, G: Antherina suraka (a similar silk, produced in Indonesia by the Circula moth has high value on the Japanese market), D. black morph larvae, E. green morph larvae, F. double, bronze colored cocoon, G. adult female; H,I,J.K: A. mittrei (similar to Circula and likely to have high value on Japanese market) H. cocoon $(\approx 5 \mathrm{~cm}$ length), I. larvae, J. double cocoon, K. recently emerged adult female.

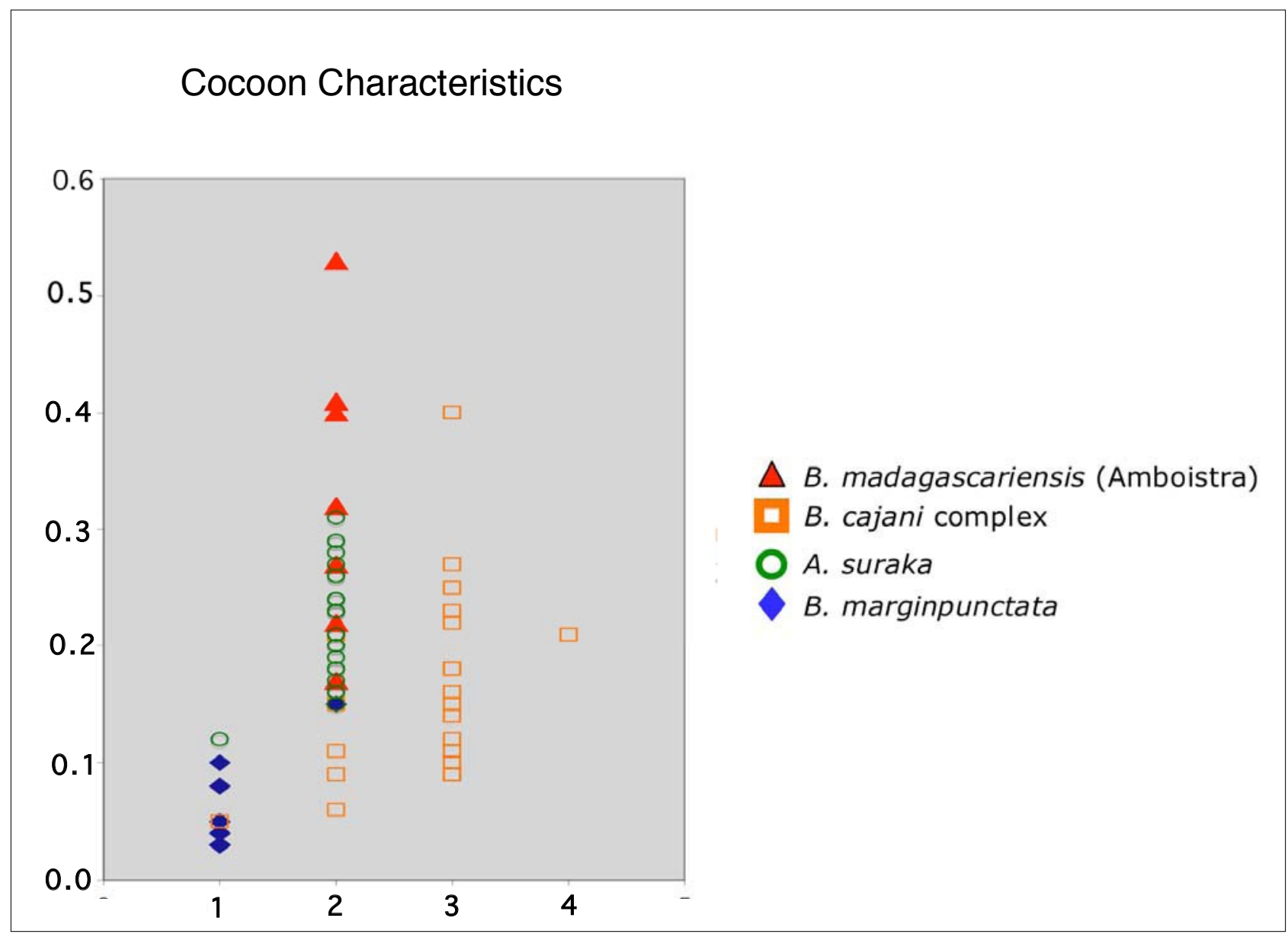

FIGURE 3. Cocoon characteristics vary within and between species. The variation in the amount of silk and number of layers of the cocoons reflect the food or different species in the reported complexes. The data show that experiments to determine the conditions under which maximum silk per cocoon is produced are needed for optimal silk production. 
TABLE 3. Value of cocoons and processed silk between 2003-2005 (pers. com., F. Checcucci, Ny Tanintsika; F. Kuroda, Royal Silk Project, H. Akai, Japanese Society for Wild Silk Moth).

\begin{tabular}{|c|c|c|c|c|}
\hline MOTH SPECIES & COCOONS/KG & COCOON VALUE & SPUN SILK VALUE & \\
\hline $\begin{array}{l}\text { Bombyx mori } \\
\text { Bombycidae } \\
\text { (Domesticated or farmed) }\end{array}$ & 1,000 & $3-6 \$ / k g$ & $25 \$ / \mathrm{kg}$ (reeled) & $\begin{array}{l}\text { Central Silk Board, Indian Silk, } \\
\text { Dec. } 2005,60 .\end{array}$ \\
\hline $\begin{array}{l}\text { B. madagascariensis } \\
\text { Lasiocampidae } \\
\text { (collected in Amboistra) }\end{array}$ & 3,000 & $2-3 \$ / k g$ & $40 \$ / k g$ & checcucci, pers. com. \\
\hline $\begin{array}{l}\text { B. cajani } \\
\text { Lasiocampidae } \\
\text { (collected in Ranomafana) }\end{array}$ & 6,250 & $2-3 \$ / \mathrm{kg}$ & $40 \$ / \mathrm{kg}$ & $\begin{array}{l}\text { Based on B. madagascarien- } \\
\text { sis }\end{array}$ \\
\hline $\begin{array}{l}\text { Antheraea pernyi } \\
\text { (Chinese tusser, reeled) } \\
\text { Saturniidae }\end{array}$ & & & $30 \$ / \mathrm{kg}$ & $\begin{array}{l}\text { Central Silk Board, Indian Silk, } \\
\text { Dec. } 2005,60 .\end{array}$ \\
\hline $\begin{array}{l}\text { Antheraea yamamai } \\
\text { (Japanese tusser) } \\
\text { Saturniidae }\end{array}$ & & & $23 \$ / k g$ & $\begin{array}{l}\text { Central Silk Board, Indian Silk, } \\
\text { Dec. } 2005,60 .\end{array}$ \\
\hline $\begin{array}{l}\text { Anaphe aurea } \\
\text { Notodontidae (Ranomafana) }\end{array}$ & 500 & $2-3 \$ / k g ?$ & $\approx 40 \$ / \mathrm{kg}$ & $\begin{array}{l}\text { H. Akai, Japanese Society for } \\
\text { Wild Silkmoths, pers.com. }\end{array}$ \\
\hline $\begin{array}{l}\text { Cricula trifenestrata } \\
\text { Saturniidae } \\
\text { (Indonesia) }\end{array}$ & 3,000 & & $225 \$ / k g$ & Kuroda, RSP, pers. com. \\
\hline $\begin{array}{l}\text { A. suraka } \\
\text { (Ranomafana) }\end{array}$ & 3,000 & & $\approx 225 \$ / \mathrm{kg}$ & $\begin{array}{l}\text { Based on Cricula trifenes- } \\
\text { trata }\end{array}$ \\
\hline $\begin{array}{l}\text { A. mittrei } \\
\text { (Ranomafana) }\end{array}$ & 1,666 & & $\approx 225 \$ / \mathrm{kg}$ & $\begin{array}{l}\text { Based on Cricula trifenes- } \\
\text { trata }\end{array}$ \\
\hline
\end{tabular}

gascariensis from the highlands. Although cocoons produced by Antherina suraka weigh half as much, as A. mittrei, A. suraka are easier to rear and more common. $A$. mittrei silk fibers, like $A$. mittrei cocoons, are porous.

Over all, the volume of silk produced by the colonial species is much lower per individual than that produced by non-colonial species. However, the colonial nests are relatively large and easy to collect. If nests are abundant, there may be a cost/benefit to collecting and processing the larger, colonial nests in contrast to individual cocoons produced by other species. If Anaphe silks are collected in future, it will be important to collect them only after the adults have emerged. Adult emergence begins in February but is not completed until the end of April. Therefore, nest collection should not begin before the middle of May.

The value of silk (Table 3) fluctuates throughout the year with moth seasonality. In Madagascar, silk produced by the domesticated silk moth, Bombyx mori, currently brings a higher value than wild silk, despite the fact that the demand for wild silk is unmet. Silk textiles are not spun from the colonial nests produced by Anaphe, although one silk shawl made from silk produced by Hypsoides, a colonial species of silkworm (from a different moth family, the Notodontidae), was found in a shop in Antananarivo. The cost was not differentiated from the cost of silk produced by Borocera species.

Silkworms in the family Saturniidae are used to produce silk textiles in India and Indonesia. Saturniid silk is considered by some experts to be superior to the silk produced by both Borocera and the domesticated silkworm, Bombyx mori, because it is porous, dyes easily, and is lightweight (Akai 2000). J-R. Estime (pers. com., Business and Market Expansion, BAMEX, Madagascar) estimates that farmers can be convinced to adopt new practices only if they yield higher income by at least a factor of 10. The silk produced by Argema mittrei is potentially such a product (Table 3 ).

Silk produced by Anaphe spp. are currently used to produce textiles in West Africa (H. Akai, pers. com.) but not in Madagascar, despite the fact that Anaphe aurea is common and widespread (Kiriakoff 1969). Anaphe moths are social and spin a group cocoon in which they undergo metamorphosis (Fig. 2a-c). The group cocoon contains 3-6 grams of silk, which can be collected, cleaned, carded and spun. 


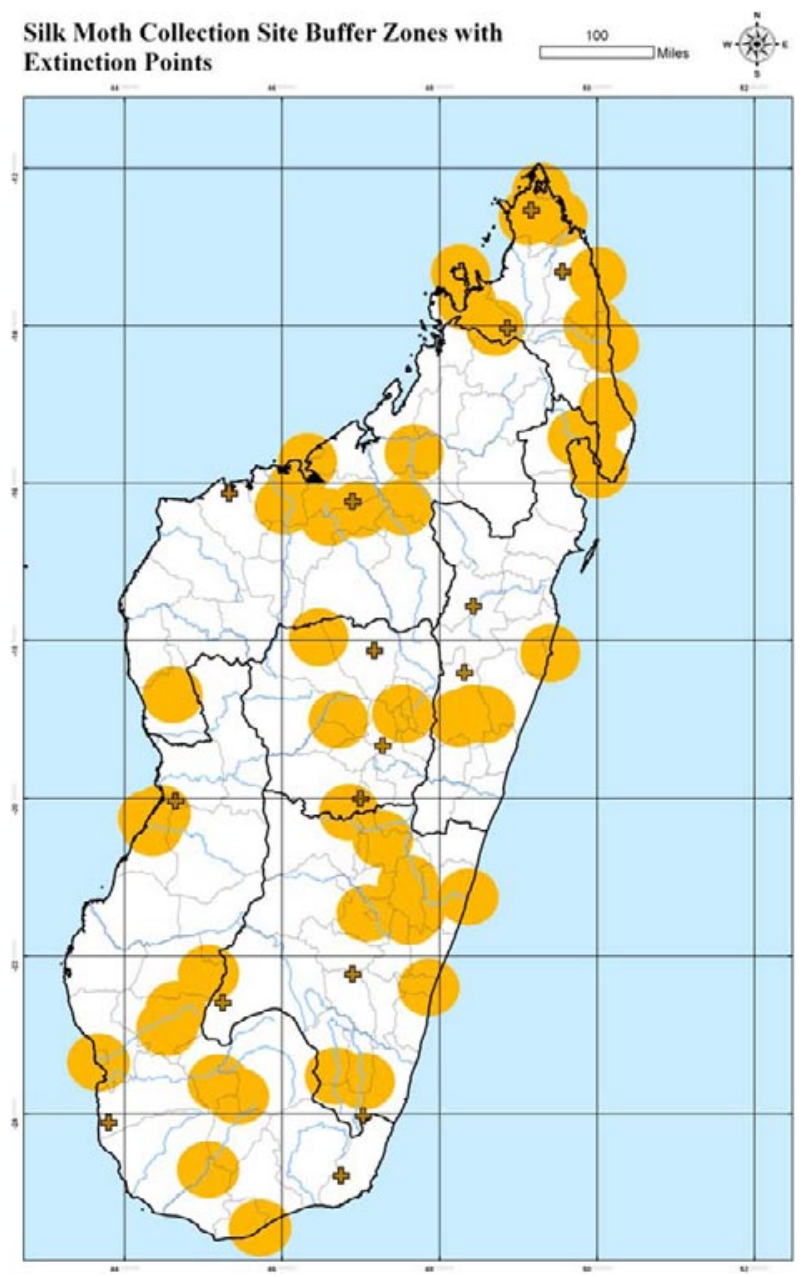

FIGURE 4. Imminent extinction points overlap with some silk moth collection sites. Light brown discs represent 25 mile buffer zones around silk moths collection sites and cross sites of imminent extinction. These data suggest 5 specific localities where wild silk production might be an effective tool for conservation and poverty alleviation.

\section{SITE SELECTION FOR MAXIMUM ECONOMIC AND CONSERVATION EFFECT}

We have taken a GIS-mapping approach to identify those sites where silk production could have its greatest positive impact on maintaining the forests and the local fauna (Figure 4). In particular, we collected data on collection localities for Borocera madagascariensis, Borocera cajani, A. suraka and A. mittrei from the Muséum National d'Histoire Naturelle, Paris and plotted them on a map of imminent extinctions for mammals, birds, amphibians and plants in Madagascar (Ricketts et al. 2005). Fifteen such sites are located in Madagascar. Five extinction sites are found within the 25-mile buffer zone surrounding silk collection sites. It may be that these areas serve as potential sites where wild silk production could contribute to forest recovery and hence vertebrate conservation. The animals found in these sites are: 1) the Forest Rock Thrush (Monticola erythronotus, Turdinae) found in Montagne d'Ambre National Park and Special Reserve, 2) the Madagascar Giant Tree Frog (Platypelis alticola, Microhylidae) found in the Tsaratanana Strict Nature Reserve and adjacent areas, 3) the Greater Big-Footed Mouse (Macrotarsomys ingens, Muridae) found in Ankarafantsika, 4) theWhite-tipped Tufted-Tail Rat (Eliurus penicillatus, Nesomyidae) found in the Ampitambe Forest and 5) the frog, (Aglyptodactylus laticeps, Mantellidae) found in the Menabe Forest.

\section{CONCLUSION}

The production of wild silk textiles is a traditional industry in Madagascar. In the past, silk cloth was produced probably using silk moths primarily in the genus Borocera. Due to over-harvesting of pupae and the destruction of native forests, wild silk production in those early sites has largely disappeared. We have found new sites and new types of silk that could be produced in Madagascar to benefit the rural poor. Furthermore, we found at least 5 potential silk producing areas that would support the maintenance and restoration of forests that protect birds, primates and amphibians threatened with imminent extinction.

\section{ACKNOWLEDGEMENTS}

We thank J. Portolese for plotting the silk moth collection sites and the Alliance for Zero Extinction for providing unpublished data on imminent extinction points. We thank the Muséum National d'Histoire Naturelle, Paris for allowing us to use their collections. The community of Ranomafana greatly assisted in this work as did the community of Centre ValBio; to them we are grateful. Finally, we thank "The Team" for their hard work in the field, high spirits and patience with the corresponding author, in particular Feliniaina Harilanto, William Rajeriarison, Emile Rajeriarison and Jean-Claude Razafimahaimodison.

\section{References}

Akai, H. 2000. Cocoon filament character and post cocoon technology. Int. J. Wild Silkmoth and Silk, 5: 71-84

Baird, I.G., and Dearden, P. 2003. Biodiversity conservation and resource tenure regimes: a case study form Northeast Cambodia. Environmental Management, 32: 541-550

Castellano, A., and San, N.N. 2005. The forest for the trees: the effect of macroeconomic factors on deforestation in Brazil and Indonesia. In: Slash-and-Burn Agriculture: the search for alternatives. C.A. Palm, S.A. Vosti, S.P.A. and P.J. Ericksen (eds.), pp 170-198. Columbia University Press, New York.

Gowdey, G.C. 1953. On the utilisation of an indigenous African silk-worm (Anaphe infracta, WLSM) in Uganda. Bulletin of Entomological Research 43:269-274

Griveaud, P. 1961. Insectes: Lépidoptères Euterotidae et Attacidae. Faune de Madagascar. pp 64. L'Institut Scientifique de Madagascar, Antananarivo.

Kiriakoff, S.G. 1969. Insects Lépidoptères Notodontidae. Faune de Madagascar. pp 228, C.N.R.S., Paris.

Kistler, P., and Spack, S. 2003. Comparing Agricultural Systems in Two Areas of Madagascar. In: Natural History of Madagascar, S.M. Goodman and J.P. Benstead (eds.), pp 123-133. Chicago University Press, Chicago.

Lajonquiere, Y.D. 1972. Insectes Lépidoptèra Lasiocampidae. Faune de Madagascar. pp 214. C.N.R.S., Paris.

Peigler, R.S. 1993. Wild Silks of the World. American Entomologist, 33: 151161

Peigler, R.S. 2004. The silk moths of Madagascar in Unwrapping the Easiest Traditions of Madagascar. UCLA Fowler Museum of Cultural History Textile Series, No. 7. C. M. Kusimba, J. C. Odland, and V. Bronson (eds.), pp 155-163. Field Museum and the UCLA Fowler Museum of Cultural History. Los Angeles.

Ricketts, T.H., Dinerstein, E., Boucher, T., Brooks, T.M., Butchart, S.H.M., Hoffmann, M., Lamoreux, J.F. 2005. Pinpointing and preventing imminent extinctions. Proceedings of the National Academy of Sciences 102: 18497-18501

Tomich, T.P., Cattaneo, A., Chater, S., Geist, H.J., Gockowski, J., Kaimowitz, D., Lambin, E.F. 2005. Balancing agricultural development and environmental objectives. In: Slash-and-Burn Agriculture: the search for alternatives, C.A. Palm, P.A. Sancherz, and P.J. Ericksen (eds.), pp 415440. Columbia University Press. New York. 